\title{
Journal of Business Management Review
}

homepage : https://profesionalmudacendekia.com/index.php/jbmr

\section{Determinant of Indonesian Islamic Banks Liquidity Risk}

\author{
Dwi Arfiyanti ${ }^{*}$, Imanda Firmatyas Putri Pertiwi ${ }^{2 *}$ \\ 1,2 Departement of Sharia Banking, Islamic Economic and Business Faculty IAIN Salatiga, Salatiga, \\ Central Java, Indonesia
}

\begin{tabular}{ll}
\hline ARTICLE INFO & ABSTRACT \\
\hline ISSN: 2723-1097 & $\begin{array}{l}\text { An assessment of the liquidity of a bank is one way to determine whether } \\
\text { the bank is in good health, fairly healthy, and unhealthy. This study aims } \\
\text { to analyze the influence of the company's internal factors consisting of }\end{array}$ \\
Keywords: & $\begin{array}{l}\text { Return on Assets, Capital Adequacy Ratio and Bank Size on the liquidity } \\
\text { ratio as measured by using two proxies, namely Liquid Asset to Total Asset }\end{array}$ \\
Return On Asset & (LATA and Financing Deposi Ratio (FDR). \\
(ROA); Capital & This study uses Islamic banks as the object of research in the 2014-2018 \\
Adequacy Ratio & period. The results of data analysis using panel data regression showed that \\
(CAR); Size; Liquid & ROA and CAR had no effect on liquidity risk. Meanwhile, bank size has a \\
Asset to Total Asset & significant negative effect on the liquidity ratio using LATA and FDR \\
(LATA); Financing to &
\end{tabular}

\section{Pendahuluan}

Menurut Undang-undang Perbankan Syariah No. 21 Tahun 2008 Perbankan Syariah memiliki fungsi menghimpun dana dari masyarakat dalam bentuk titipan dan investasi dari pihak pemilik dana. Fungsi lainnya ialah menyalurkan dana kepada pihak lain yang membutuhkan dana dalam bentuk jual beli maupun kerjasama usaha. maka Bank Syariah sendiri hadir menjadi lembaga intermediasi antara pihak yang kelebihan dana dengan pihak yang membutuhkan dana (Ismail, 2011).

Dalam menjalankan fungsinya sebagai lembaga intermediasi, bank dituntut memiliki strategi untuk menentukan kebijakan dalam rangka menghimpun dan menyalurkan dananya karena kedua kegiatan tersebut berdampak terhadap besar atau kecilnya tingkat likuiditas bank. Dalam aktivitasnya sebagai lembaga intermediasi, kegiatan bank sangat erat kaitannya dengan likuiditas (Bramantya \& Arfinto, 2015).

Kajian mengenai likuiditas di dunia perbankan merupakan satu keharusan yang harus dilakukan, baik itu oleh pihak perbankan, praktisi keuangan, ataupun pihak-pihak ketiga yang berencana menitipkan dananya di bank. Pentingnya penilaian atas likuiditas suatu bank merupakan salah satu cara untuk bisa menentukan apakah bank tersebut dalam kondisi sehat, cukup sehat, kurang sehat dan tidak sehat (Sinungan, 1993).

Journal of Business and Management Review Vol. 1 No. 42020 Page 281 294

DOI: $10.47153 / \mathrm{jbmr} 14.332020$

*Corresponding Author

Email Address: dwiarfiyanti901@gmail.com 
Likuiditas merupakan rasio yang menunjukkan kemampuan perusahaan dalam memenuhi kewajiban jangka pendeknya yang jatuh tempo (Kasmir, 2016). Penilaian suatu bank dari aspek likuiditas salah satunya dapat dilihat dengan menggunakan Ratio of Liquid Asset to Total Asset. Ratio of Liquid Asset to Total Asset adalah rasio yang digunakan untuk mengukur tingkat likuiditas bank, yang membandingkan antara Liquid Asset (Aset Lancar) dengan Total Asset (jumlah aset). Jika kas yang tersedia pada sebuah bank terlalu besar, menandakan bahwa kondisi bank tersebut tidak efisien. Sehingga perusahaan harus memiliki tingkat ketersediaan jumlah kas yang baik agar dapat memenuhi kewajiban jangka pendeknya yang akan segera jatuh tempo (Nugraheni, Febrianti, \& Alam, 2011).

Aspek likuiditas yang kedua menggunakan Financing to Deposit Ratio (FDR). FDR dapat mengindikasikan kemampuan yang ada pada bank dengan menggunakan dana pihak ketiga untuk disalurkan kepada pemohon dan juga kemampuan bank memperoleh dana yang dipinjam untuk dikembalikan kepada deposan berdasarkan pembiayaan yang berperan sebagai sumber likuiditas (Kasmir, 2007).

Semakin tinggi rasio ini maka kemampuan bank tersebut akan semakin baik dalam mengelola fungsi intermediasi secara optimal. Namun, semakin tinggi rasio ini maka likuiditas bank tersebut akan menurun karena dana lebih banyak dialokasikan untuk pembiayaan. Sebaliknya, semakin rendah rasio ini bank akan semakin likuid dikarenakan akan banyaknya dana yang menganggur (idle fund) karena fungsi intermediasi tidak tercapai dengan baik sehingga akan memperkecil kesempatan bank untuk memperoleh penerimaan yang lebih besar (Ramadhani \& Indriani, 2016).

Dalam penelitian ini, variabel yang digunakan adalah beberapa variabel yang termasuk dalam faktor internal yang mempengaruhi tingkat likuiditas bank syariah. Beberapa variabel-variabel yang termasuk dalam faktor internal terdiri dari Return On Asset (ROA), Capital Adequacy Ratio (CAR) dan Size (Ukuran Bank).

Profitabilitas yang diproksikan dengan Return On Asset menunjukkan efektivitas perusahaan dalam menghasilkan keuntungan dengan mengoptimalkan aset yang dimiliki. Menurut (Almilia, 2005 dalam Bramantya \& Arfinto, 2015) Capital Adequacy Ratio (CAR) merupakan rasio yang menunjukkan kemampuan bank dalam mempertahankan modal yang mencukupi dan kemampuan manajemen bank dalam mengidentifikasi, mengukur, mengawasi dan mengontrol resiko-resiko yang timbul yang dapat berpengaruh terhadap besarnya modal. Sedangkan Size ( ukuran Bank) merupakakan ukuran besar kecilnya sebuah perusahaan yang ditunjukkan atau dinilai oleh total asset, total penjualan, jumlah laba, beban pajak dan lain-lain (Brigham \& Houston 2010).

Tujuan penelitian ini dapat dirumuskan sebagai berikut: 1) Menganalisis pengaruh Return on Asset (ROA) terhadap Liquid Asset to Total Asset (LATA) dan Financing to Deposit Ratio (FDR). 2) Menganalisis pengaruh Capital Adequacy Ratio (CAR) terhadap Liquid Asset to Total Asset (LATA) dan Financing to Deposit Ratio (FDR). 
3) Menganalisis pengaruh Size (Ukuran Bank) terhadap Liquid Asset to Total Asset (LATA) dan Financing to Deposit Ratio (FDR).

\section{The Shiftability Theory}

Teori ini mengemukakan bahwa apabila bank mempunyai harta (assets) yang dapat dengan mudah digeser atau dijual maka bank tersebut dapat mempertahankan likuiditasnya. Bank akan segera mendapatkan uang tunai (likuiditas) jika menjual assetnya. Menurut teori ini, likuiditas perbankan dapat dipertahankan apabila dana yang dihimpun ditanamkan dalam surat berharga yang marketable, yang mana dapat mudah dicairkan dalam bentuk uang kas (Fahmi, 2015).

\section{The Liability Management Theory}

Menurut teori ini, likuiditas bank dapat dijamin jika bank untuk memenuhi kewajiban keuangannya mencari uang di pasar uang. Dalam arti luas pasar uang meliputi pinjaman dari bank-bank lain atau bank sentral. Teori ini menitik beratkan pada segi liability (pengelolaan utang) kaitannya dengan pengelolaan assets dan liability, jika bank kekurangan likuiditas permasalahan yang harus ditekankan ialah terletak pada liability management (Pandia, 2012).

\section{Pecking Order Theory}

Pecking order theory menyatakan bahwa perusahaan menyukai internal financing (pendanaan dari hasil operasi perusahaan), perusahaan mencoba menyesuaikan rasio pembagian dividen yang ditargetkan, dengan berusaha menghindari perubahan pembayaran dividen secara drastis, kebijakan dividen yang relatif cenderung kaku, disertai dengan fluktuasi profitabilitas dan kesempatan investasi yang tidak bisa diduga, mengakibatkan bahwa dana hasil operasi kadang-kadang melebihi kebutuhan dana untuk investasi, meskipun pada kesempatan yang lain, mungkin kurang. Apabila dana hasil operasi kurang dari kebutuhan investasi (capital expenditure), maka perusahaan akan mengurangi saldo kas atau menjual sekuritas yang dimiliki, apabila pendanaan dari luar (external financing) diperlukan, maka perusahaan akan menerbitkan sekuritas yang paling "aman" terlebih dulu dimulai dengan penerbitan obligasi, kemudian diikuti oleh sekuritas yang berkarakteristik opsi (seperti obligasi konversi) baru akhirnya apabila masih belum mencukupi, saham baru diterbitkan (Husnan, 2012) dalam (Juliantika \& Dewi S, 2016).

\section{Liquid Asset to Total Asset.}

Liquid Asset to Total Asset adalah rasio yang digunakan untuk mengukur tingkat likuiditas bank, yang membandingkan antara Liquid Asset (Aset Lancar) dengan Total Asset (jumlah aset). Jika kas yang tersedia pada sebuah bank terlalu besar, menandakan bahwa kondisi bank tersebut tidak efisien. Sehingga perusahaan harus memiliki tingkat ketersediaan jumlah kas yang baik agar dapat memenuhi kewajiban jangka pendeknya yang akan segera jatuh tempo [11]. Rasio Liquid Asset to Total Asset (LATA) yang tinggi menandakan semakin besar kemampuan bank dalam memenuhi kewajiban jangka pendeknya. Dengan demikian risiko likuiditas yang dihadapi bank akan semakin kecil.

\section{Financing To Deposit Ratio (FDR)}


Financing to Deposit Ratio (FDR) adalah kemampuan yang ada pada bank dengan menggunakan dana pihak ketiga untuk disalurkan kepada pemohon dan juga kemampuan bank memperoleh dana yang dipinjam untuk dikembalikan kepada deposan berdasarkan pembiayaan yang berperan sebagai sumber likuiditas [6]. Rasio FDR yang tinggi menandakan likuiditas bank yang rendah dan mengakibatkan tingginya risiko likuiditas, karena jumlah dana yang diperlukan untuk pembiayaan atau pemberian kredit semakin besar [5].

\section{Return On Asset (ROA)}

Return On Asset (ROA) adalah rasio yang mengukur efektivitas perusahaan didalam menghasilkan keuntungan dengan memanfaatkan aktiva yang dimilki perusahaan [12]. ROA merupakan parameter akuntansi yang paling kompre-hensif dalam mengukur kinerja perbankan dan menjadi indicator effisiensi dan kemampuan manajemen bank dalam menghasilkan laba dari kegiatan operasionalnya [5].

\section{Capital Adequacy Ratio (CAR)}

Capital Adequacy Ratio (CAR) Adalah rasio permodalan yang memperlihatkan seberapa besar jumlah seluruh aktiva bank yang mengandung unsur risiko (kredit, penyertaan, surat berharga, tagihan pada bank lain) ikut dibiayai dari modal sendiri disamping memperoleh dana-dana dari sumber diluar bank[13]. Capital Adequacy Ratio (CAR) digunakan sebagai indikator dari kemampuan bank untuk menutupi penurunan aktiva sebagai akibat dari kerugian - kerugian yang disebabkan oleh aktiva berisiko. Rasio ini bertujuan untuk memastikan bahwa jika dalam aktivitasnya bank mengalami kerugian, maka ketersediaan modal yang dimiliki oleh bank dapat menutup kerugian tersebut

\section{Size (Ukuran Bank)}

Size (Ukuran bank) didefinisikan sebagai ukuran besar kecilnya suatu bank tersebut, ukuran bank dapat dinyatakan dalam total aktiva, penjualan dan kapitalisasi [14].

\section{ROA dan Rasio Likuiditas}

Penilaian aspek likuiditas menunjukkan kemampuan bank untuk mengelola tingkat likuiditas yang memadai dalam rangka memenuhi kewajibannya secara tepat waktu dan untuk memenuhi kebutuhan yang lain [5]. semakin tinggi ROA maka membuktikan bahwa semakin optimal penggunaan aktiva perusahaan untuk memperoleh pendapatan, yang berarti adanya ketersediaan dana saat ini dan di masa mendatang untuk kegiatan kredit oleh bank telah optimal dalam mendapatkan pendapatan atau keuntungan, sehingga adanya ketersediaan dana saat ini dan di masa mendatang (likuiditas tinggi) [15]. Hasil penelitian [15], [16] menunjukkan bahwa ROA mempunya pengaruh positif terhadap rasio likuiditas. Berdasarkan uraian di atas maka hipotesis pertama penelitian ini dibagi menjadi dua yaitu 
H1a: ROA berpengaruh positif terhadap LATA

H1b: ROA berpengaruh positif terhadap FDR

\section{CAR dan Risiko Likuiditas}

Peningkatan maupun penurunan rasio kecukupan modal berpengaruh pada perilaku bank. Semakin tinggi nilai CAR, menunjukkan semakin tinggi tingkat likuiditas bank tersebut, sehingga struktur modal bank semakin kuat. Semakin kuatnya struktur modal yang dimiliki oleh bank, maka bank akan dapat menjaga likuiditasnya dengan baik.. Fungsi modal bank salah satunya yakni untuk memenuhi kebutuhan modal minimum, tingkat kecukupan modal sangat penting bagi bank untuk menyalurkan kreditnya. Bila tingkat kecukupan modal bank baik, maka masyarakat akan tertarik untuk mengambil kredit, dan pihak bank akan cukup mempunyai dana cadangan bila sewaktu-waktu terjadi kredit macet [15]. Hasil penelitian $(((([15]$, [17] menunjukkan bahwa CAR berpengaruh positif terhadap risiko likuiditas. Berdasarkan uraian tersebut maka hipotesis kedua penelitian ini yaitu

H2a. CAR berpengaruh positif terhadap LATA

H2b. CAR Berpengaruh positif terhadap FDR

\section{Ukuran Perusahaan dan Risiko Likuiditas}

Ukuran bank yang ditandai dengan jumlah aset yang dimiliki oleh bank, maka dalam menanggung risiko tersebut memiliki peluang yang lebih besar pula. Risiko yang ditanggung berupa semakin besarnya jumlah kewajiban yang harus segera dibayar sebelum jatuh tempo. Ukuran bank yang diukur menggunakan total asset memiliki pengaruh negatif terhadap risiko likuiditas karena pada bank apabila semakin besar bank maka semakin banyak juga asset yang dimiliki sehingga tidak perlu khawatir dengan beban yang akan jatuh tempo [18]. Hasil penelitian [18]-[20] menunjukkan bahwa ukuran perusahaan berpengaruh negatif terhadap risiko likuiditas. Berdasarkan uraian di atas maka hipotesis ketiga dalam penelitian ini yaitu

H3a. Ukuran bank berpengaruh negatif terhadap LATA

H3b. ukuran bank berpengaruh negatif terhadap FDR

\section{Metode}

Pada penelitian ini digunakan dua jenis variabel penelitian yaitu variabel dependen $(Y)$ dan variabel independen $(X)$. Variabel-variabel yang dibutuhkan dalam penelitian ini ada lima yang terdiri dari dua variabel dependen yaitu LATA (Y1), FDR (Y2) serta tiga variabel independen yaitu ROA (X1), CAR (X2), dan SIZE (X3). Jenis penelitian yang digunakan dalam penelitian ini adalah penelitian kuantitatif. Data 
yang digunakan dalam penelitian ini data sekunder berupa panel data Bank Umum Syariah yang telah terdaftar di Otoritas Jasa Keuangan (OJK) dalam bentuk laporan keuangan tahunan (annual Report) yang diperoleh dari situs www.ojk.go.id dan situs web Bank Syariah yang berkaitan. Metode pengumpulan data dari studi literatur dan laporan keuangan tahunan.

Populasi yang digunakan dalam penelitian ini adalah 14 bank umum syariah di Indonesia yang terdaftar di Otoritas Jasa Keuangan (OJK) periode tahun 2014 hingga tahun 2018. Teknik penarikan sampel yang digunakan dalam penelitian ini adalah metode purposive sampling. Metode purposive sampling yaitu teknik penentuan sampel dengan pertimbangan-pertimbangan atau kriteria-kriteria tertentu. Melalui purposive sampling didapatkan sampel 11 bank yang memenuhi kriteria untuk dijadikan sampel penelitian.

Analisis data yang digunakan dalam penelitian ini yaitu menggunakan analisis regresi linier berganda. Dan dalam melakukan perhitungan menggunakan metode statistik yang dibantu dengan program pengolah data Eviews versi 10. Eviews adalah program komputer yang digunakan untuk mengolah data statistik dan data ekonometrika.

\section{Definisi Operasional Variabel}

Tabel 1. Definisi Operasional

\begin{tabular}{ll}
\hline \multicolumn{1}{c}{ Variabel } & \multicolumn{1}{c}{ Definisi Operasional } \\
\hline Liquid Asset to Total Asset (Y1) & LATA $=\frac{\text { Liquid Asset }}{\text { Total Asset }} \times 100 \%$ \\
Financing to Deposit Ratio (Y2) & FDR $=\frac{\text { Total Pembiayaan }}{\text { Total Dana Pihak Ketiga }} \times 100 \%$ \\
Return On Asset $(X 1)$ & ROA $=\frac{\text { laba Sebelum Pajak }}{\text { Rata-rata } \text { Total Asset }} \times 100 \%$ \\
Capital Adequacy Ratio (X2) & CAR $=\frac{\text { Modal Bank }}{\text { Total ATMR }} \times 100$ \\
Size $(\mathrm{X} 3)$ & Size $=$ LnTotal Asset \\
\hline
\end{tabular}

\section{Hasil Penelitian Dan Pembahasan}

Statistik deskriptif digunakan untuk menunjukkan jumlah data yang digunakan dalam penelitian ini serta nilai maksimum, nilai minimum, nilai rata-rata (mean) dan tingkat sebaran data atau standar deviasi dari masing-masing variabel yang digunakan.

Tabel 2.Statistik Deskriptif Penelitian

\begin{tabular}{lcccccc}
\hline $\begin{array}{c}\text { Statistik } \\
\text { Deskriptif }\end{array}$ & Obvervasi & Mean & Median & Maksimum & Minimum & $\begin{array}{c}\text { Standar } \\
\text { Deviasi }\end{array}$ \\
\hline LATA & 55 & 23.9 & 24.2 & 41.2 & 0.1 & 9.1 \\
FDR & 55 & 87.5 & 90.1 & 100.6 & 69.4 & 7.4 \\
ROA & 55 & 1.1 & 0.6 & 10.7 & -11.2 & 2.8 \\
CAR & 55 & 18.7 & 18.7 & 40.9 & 3.5 & 7.3 \\
SIZE & 55 & 19.5 & 18.1 & 24.1 & 15.1 & 2.9 \\
\hline
\end{tabular}




\section{Analisis Regresi Linear Berganda}

Penelitian ini melakukan uji analisis regresi linier berganda dengan menggunakan uji koefisien determinasi $\left(R^{2}\right)$, uji signifikansi parameter individual (uji statistik t) dan uji signifikansi simultan (uji statistik F).

\section{Koefisien determinasi $\left(R^{2}\right)$ dan Uji F}

Koefisien determinasi $\left(\mathrm{R}^{2}\right)$ pada intinya digunakan untuk mengukur seberapa jauh kemampuan model dalam menerangkan variasi variabel dependen. Berikut adalah hasil uji koefisien determinasi:

Tabel 3. Hasil Uji Koefisien Determinasi Variabel LATA

\begin{tabular}{lrll}
\hline R-squared & 0.819339 & Mean dependent var & 25.05521 \\
Adjusted R-squared & 0.732124 & S.D. dependent var & 8.898069 \\
S.E. of regression & 4.605353 & Akaike info criterion & 6.157240 \\
Sum squared resid & 615.0691 & Schwarz criterion & 6.765487 \\
Log likelihood & -120.4593 & Hannan-Quinn criter. & 6.382807 \\
F-statistic & 9.394415 & Durbin-Watson stat & 2.048850 \\
Prob(F-statistic) & 0.000000 & & \\
\hline
\end{tabular}

Sumber : Data sekunder yang diolah, 2020

Berdasarkan hasil uji koefisien determinasi menunjukkan bahwa nilai adjusted R-Squared sebesar 0,732124 menunjukkan kemampuan dalam menjelaskan pengaruh dependen sebesar 73,21\%. Sisanya sebesar 26,79\% dijelaskan oleh variasi lain di luar penelitian. Selain itu dilihat dari probabilitas F-statitistic menunjukkan bahwa nilainya di bawah 0,05 yang artinya model penelitian ini layak.

Tabel 4. Hasil Uji Koefisien Determinasi Variabel FDR

\begin{tabular}{lrll}
\hline R-squared & 0.540965 & Mean dependent var & 86.62750 \\
Adjusted R-squared & 0.493885 & S.D. dependent var & 7.760855 \\
S.E. of regression & 5.521210 & Akaike info criterion & 6.361716 \\
Sum squared resid & 1188.867 & Schwarz criterion & 6.564465 \\
Log likelihood & -134.9578 & Hannan-Quinn criter. & 6.436905 \\
F-statistic & 11.49022 & Durbin-Watson stat & 2.021815 \\
Prob(F-statistic) & 0.000003 & & \\
\hline
\end{tabular}


Berdasarkan hasil uji koefisien determinasi menunjukkan bahwa nilai Adjusted RSquared sebesar 0,493885 menunjukkan kemampuan dalam menjelaskan pengaruh dependen sebesar 49,39\%. Sisanya sebesar 50,61 \% dijelaskan oleh variasi lain di luar penelitian. Nilai probabilitas dari F statistik menunjukkan nilai yang signifikan dengan probabilitas kurang dari 0,05 menunjukkan bahwa model layak.

\section{Uji Signifikansi Parameter Individual (Uji Statistik t)}

Uji statistik $\mathrm{t}$ pada dasarnya menunjukkan seberapa jauh pengaruh satu variabel independen secara individual dalam menerangkan variabel dependen (Ghozali, 2011).

Tabel 2. Hasil Uji Statistik t Variabel LATA

\begin{tabular}{crrrr}
\hline Variable & Coefficient & Std. Error & t-Statistic & Prob. \\
\hline \hline C & 20.90726 & 1.737568 & 12.03249 & 0.0000 \\
D(LOG(CAR) $)$ & -1.125220 & 1.672324 & -0.672848 & 0.5064 \\
D(ROA) & -0.067168 & 0.068882 & -0.975112 & 0.3376 \\
D(LOG(SIZE) $)$ & -44.36782 & 11.12692 & -3.987429 & 0.0004 \\
LATA(-1) & 0.190076 & 0.038492 & 4.938085 & 0.0000 \\
\hline \hline
\end{tabular}

Sumber : Data sekunder yang diolah, 2020

Tabel 3. Hasil Uji Statistik t Variabel FDR

\begin{tabular}{crrrr} 
Variable & Coefficient & Std. Error & t-Statistic & Prob. \\
\hline \hline C & 14.62703 & 5.456010 & 2.680903 & 0.0107 \\
D(LOG(CAR)) & 3.127764 & 2.845536 & 1.099183 & 0.2784 \\
D(ROA) & 0.071205 & 0.133839 & 0.532020 & 0.5977 \\
D(LOG(SIZE) $)$ & -50.56404 & 18.68158 & -2.706625 & 0.0100 \\
FDR(-1) & 0.814176 & 0.067150 & 12.12474 & 0.0000 \\
\hline \hline
\end{tabular}

Sumber : Data sekunder yang diolah, 2020

H1a : Return On Asset tidak berpengaruh terhadap Liquid Asset to Total Asset.

ROA tidak berpegaruh terhadap LATA. Hal tersebut dikarenakan Bank Syariah tidak menggunakan keuntungan yang didapat untuk menutupi kewajiban. Bank Syariah menggunakan sistem bagi hasil dimana hal tersebut, harus dibayarkan meskipun bank tersebut mengalami kerugian akibat pembiayaan yang diberikan, 
maka bank menggunakan sebagian ekuitas nya untuk membayar bagi hasil kepada nasabahnya dan juga kewajiban jangka pendeknya (Bani \& Yaya, 2016). Hasil penelitian ini didukung oleh penelitian yang dilakukan (Ramzan \& Zafar, 2014) dan (Shibly \& Nimsith, 2015) yang menunjukkan bahwa Return On Asset (ROA) tidak berpengaruh terhadap Liquid Asset to Total Asset.

\section{H1b : Return On Asset tidak berpengaruh terhadap Financing to Deposit Ratio.}

ROA tidak berpegaruh terhadap FDR. Disebabkan karena adanya pemanfaatan jasa lain diluar kegiatan operasional utama bank dimana sumber pendapatan bank umumnya berasal dari bagi hasil atas pengembalian dana dari nasabah. Diindikasikan bank saat ini sedang melakukan penguatan internal dengan mengutamakan perolehan laba yang tinggi dengan menyediakan kegiatan jasa lain dibandingkan dengan mengeluarkan dananya dalam memenuhi kewajiban (Putri \& Suryantini, 2017). Hasil penelitian ini sejalan dengan penelitian yang dilakukan oleh (Utari \& Haryanto, 2011), (Nugraha, 2014), (Hermawan, 2009) yang menunjukkan bahwa Return On Asset (ROA) berpengaruh tidak signifkan terhadap Financing to Deposit Ratio (FDR).

\section{H2a : Capital Adequacy Ratio tidak berpengaruh terhadap Liquid Asset to Total Asset.}

Hasil penelitian tersebut menunjukkan CAR berpengaruh tidak signifikan terhadap LATA. Oleh karenanya Bank Syariah tidak memiliki kemampuan yang bagus untuk menggunakan modal guna membayar kewajiban jangka pendeknya. Perbankan syariah menggunakan modal mereka untuk melakukan kegiatan ekonominya dan terus menyalurkan pembiayaan guna memperoleh keuntungan. Meskipun demikian bank harus menjaga ketersediaan modal sesuai dengan peraturan Bank Indonesia. Karena akan ada kemungkinan penyediaan likuiditas bank akan diambil dari permodalan untuk menutupi risiko kerugian yang dialami oleh bank (Muharam \& Kurnia, 2013). Hasil penelitian ini didukung oleh penelitian yang dilakukan (Muharam \& Kurnia, 2013) dan (Shibly \& Nimsith, 2015) yang menunjukkan bahwa Capital Adequacy Ratio (CAR) berpengaruh negatif dan tidak signifikan terhadap Liquid Asset to Total Asset.

\section{H2b : Capital Adequacy Ratio tidak berpengaruh terhadap Financing to Deposit Ratio.}

Capital Adequacy Ratio (CAR) tidak berpengaruh signifikan terhadap tingkat likuiditas karena penurunan CAR bisa disebabkan oleh penurunan modal dan laba disertai dengan kenaikan ATMR. Peningkatan ATMR bisa terjadi karena semakin besar pembiayaan yang disalurkan oleh bank maka semakin besar pula ATMR bank yang bersangkutan sehingga CAR akan turun. Peningkatan CAR bisa disebabkan karena terjadi peningkatan modal sendiri. Karena terjadi peningkatan modal sendiri maka biaya dana akan menurun sehingga likuiditas justru akan menurun. Jadi, 
peningkatan nilai CAR disertai kenaikan likuiditas bisa saja terjadi jika terjadi peningkatan modal sendiri yang dimiliki oleh bank (Utari \& Haryanto, 2011).

Menurut penelitian yang dilakukan oleh Putri \& Suryantini (2017) CAR tidak signifikan terhadap Likuiditas karena adanya masalah dalam penyaluran pembiayaan yang dapat menjadi pemicunya dimana bank memiliki ketakutan untuk menyalurkan pembiayaan dalam jumlah yang besar karena tidak ingin mengambil risiko yang tinggi. Bank yang ada di Indonesia terindikasi sedang berupaya menjaga tingkat pemenuhan modal minimumnya, agar bank senantiasa berada pada kondisi sehat. Dampaknya adalah bank tidak menyanggupi melakukan penyaluran pembiayaan karena bank tidak ingin menanggung risiko seperti adanya pembiayaan bermasalah.

\section{H3a : size berpengaruh negatif signifikan terhadap liquid asset to total asset.}

Semakin besar ukuran perusahaan yang ditunjukkan dengan total asset yang besar, memiliki peluang yang lebih besar pula dalam meningkatkan risiko yang ditanggung oleh pihak bank. Risiko yang ditanggung ini berupa semakin banyaknya beban beban yang harus dibayar segera sebelum jatuh tempo (Azhary \& Muharam, 2017). Size yang diukur menggunakan total asset memiliki pengaruh negatif terhadap risiko likuiditas karena pada bank apabila semakin besar bank maka semakin banyak juga asset yang dimiliki sehingga tidak perlu khawatir dengan beban yang akan jatuh tempo (A. Abdullah \& Khan, 2012). Hasil ini didukung oleh penelitian Vodova (2013), A. Abdullah \& Khan (2012) dan Mahmood et al., (2019) yang menyatakan bahwa Size (Ukuran Bank) berpengaruh negatif dan signifikan terhadap Liquid Asset to Total Asset.

$\mathrm{H} 3 \mathrm{~b}$ : size berpengaruh negatif signifikan terhadap Financing to Deposit Ratio (FDR).

Tingginya likuiditas bank, mengindikasikan tingkat FDR menjadi semakin rendah karena banyak dana yang tidak dialokasikan ke dalam bentuk pembiayaan, melainkan digunakan untuk mengimbangi kewajibannya dalam memenuhi permintaan deposan yang ingin menarik kembali uangnya yang telah digunakan oleh bank untuk memberikan pembiayaan (Dendawijaya, 2005).

Hasil penelitian ini diperkuat dengan penelitian Endri (2009) menyatakan bahwa rendahnya LDR bank disebabkan oleh kekhawatiran akan terjadi kredit macet sehingga kelebihan aset lebih cenderung ditempatkan pada instrument yang lebih aman dengan keuntungan yang pasti yaitu Sertifikat Bank Indonesia (SBI) dan pembelian obligasi pemerintah yang memiliki tingkat suku bunga cukup tinggi dan risiko rendah. Hasil ini didukung oleh penelitian Mahmood et al., (2019), Zaghdoudi \& Hakimi (2017) dan Moussa (2015) yang menyatakan bahwa Size (Ukuran Bank) berpengaruh negatif dan signifikan terhadap Financing to Deposit Ratio.

\section{Kesimpulan Dan Saran}

Berdasarkan hasil analisis data maka dapat disimpulkan bahwa ROA dan CAR tidak memiliki pengaruh terhadap rasio likuiditas yang diukur dengan menggunakan 
LATA dan FDR. Adapun Bank Size menunjukkan pengaruhnya secara positif terhadap LATA dan FDR.

Untuk penelitian selanjutnya dapat menambahkan variabel lainnya yang berhubungan dengan likuiditas. Penelitian ini hanya dilakukan pada Bank Umum Syariah di Indonesia. Penelitian berikutnya, dapat melakukan penelitian dengan objek yang berbeda misalnya, pada sektor Unit Usaha Syariah (UUS) dan Bank Pembiayaan Rakyat Syariah (BUS). Penelitian ini hanya menggunakan sampel sebanyak 11 perusahaan dan menggunakan periode pengamatan dari tahun 2014-2018. Penelitian yang selanjutnya diharapkan dapat menambahkan jumlah sampel penelitian dan memperpanjang periode pengamatan yang akan digunakan sehingga kedepannya dapat menghasilkan penelitian yang akan lebih baik.

\section{Pengakuan}

Terimakasih kepada kedua orang tua penulis yang telah memberikan dukungan moril dan materil dan terimakasih kepada dosen pembimbing serta kepada semua pihak yang telah membantu penulis menyelesaikan penelitian ini.

\section{Referensi}

Abdullah, A., \& Khan, A. Q. (2012). Liquidity Risk Management: A Comparative Study between Domestic and Foreign Banks in Pakistan. Journal of Managerial Sciences.

Abdullah, M. F. (2005). Dasar-dasar Manajemen Keuangan Edisi kedua. Malang: Penerbitan Universitas Muhammadiyah.

Azhary, A., \& Muharam, H. (2017). Analisis Faktor-Faktor yang mempengaruhi risiko likuiditas pada bank konvensional (Studi pada Bank yang Termasuk Badan Usaha Milik Pemerintah dan Bank Asing di Indonesia dan Malaysia Periode Tahun 2011 sampai dengan 2015). Diponegoro Journal Ofmanagement.

Bani, F., \& Yaya, R. (2016). Risiko Likuiditas pada Perbankan Konvensional dan Syariah di Indonesia. 16(1), 1-26.

Bramantya, B., \& Arfinto, E. D. (2015). Analisis Pengaruh Size , Profitability , Capital Adequacy, Dan Non-Performing Loan Terhadap Likuiditas Bank Umum Yang Terdaftar Di Bursa Efek Indonesia Periode 2011-2014. Diponegoro Journal Of Management, 4, 1-9.

Brigham \& Houston. (2010). Dasar - dasar Manajemen Keuangan Buku I. Jakarta: Salemba Empat.

Dendawijaya, L. (2003). Manajemen Perbankan. Jakarta: Balai Pustaka.

Dendawijaya, L. (2005). Manajemen Perbankan. Bogor: Ghalia Indonesia. 
Endri. (2009). Penguatan Stabilitas Sistem Keuangan Melalui Peningkatan Fungsi Intermediasi Dan Efisiensi Bank Pembangunan Daerah (BPD). Jurnal Keuangan Dan Perbankan, 13(1), 120-134.

Fahmi, I. (2015). Manajemen Keuangan Perusahaan. Jakarta: Mitra Wacana Media.

Ghozali, I. (2011). Aplikasi Analisis Multivariate Dengan Program SPSS. Semarang: Badan Penerbit Universitas Diponegoro.

Hanafi, M., \& Halim, A. (2005). Analisis Laporan Keuangan. Yogyakarta: UPP AMP YKPN.

Hermawan, J. (2009). Pengaruh Rentabilitas Dan Solvabilitas Terhadap Likuiditas Pada Perusahaan Perbankan Yang Go Public. In Skripsi. Fakultas Ekonomi Universitas Sumatera Utara.

Hersugondo, \& Tamtomo, H. S. (2012). Pengaruh CAR, NPL, DPK Dan ROA Terhadap LDR Perbankan Indonesia. Jurnal FE Universitas Stikubank Semarang.

Ismail. (2011). Perbankan Syariah. Jakarta: Prenadamedia Group.

Juliantika, N. L. A. A. ., \& Dewi S, M. R. (2016). Perusahaan Property Dan Realestate. E-Jurnal Manajemen Unud, 5(7), 4161-4192.

Kasmir. (2007). Manajemen Perbankan. Jakarta: PT. RajaGrafindo Persada.

Kasmir. (2016). Analisis Laporan Keuangan. Jakarta: Raja Grafindo Persada.

Kuncoro, M., \& Suhardjono. (2002). Manajemen Perbankan (Teori dan Aplikasi) I. Yogyakarta: Badan Penerbit Fakultas Ekonomi UGM.

Mahmood, H., Khalid, S., Waheed, A., \& Arif, M. (2019). Impact of Macro Specific Factor and Bank Specific Factor on Bank Liquidithy using FMOLS Approac. Emerging Science Journal, 3(3), 168-178.

Moussa, M. A. Ben. (2015). The Determinants of Bank Liquidity : Case of Tunisia. 5(1), 249259.

Muharam, H., \& Kurnia, H. P. (2013). Liquidity Risk On Banking Industry: Comparative Study Between Islamic Bank And Conventional Bank In Indonesia. Al-Iqtishad, Vol. V, No.

Nugraha, R. E. (2014). Analisis Pengaruh Capital Adequacy Ratio (CAR), Non Performing Loan (NPL), Biaya Operasional Pendapatan Operasional (BOPO), Return On Asset (ROA) Dan Net Interest Margin (NIM) Terhadap Loan To Deposit Ratio (LDR) (Studi Empiris Pada Perbankan Syariah Di I. Naskah Publikasi, $1-16$. 
Nugraheni, P., Febrianti, W., \& Alam, I. (2011). Pengaruh Risiko Likuiditas Terhadap Profitabilitas Pada Perbankan Syariah dan Konvensional di Indonesia. Jurnal Akuntansi E Investasi, 387656(174).

Pandia, F. (2012). Manajemen Dana dan Kesehatan Bank. Jakarta: PT. Rineka Cipta.

Putri, I. G. A. P. T., \& Suryantini, N. P. S. (2017). Determinasi Loan To Deposit Ratio Pada Bank Campuran Di Indonesia. E-Jurnal Manajemen Unud, 6(1), 204-234.

Ramadhani, A. N., \& Indriani, A. (2016). Analisis Pengaruh Size , Capital Adequacy Ratio (CAR), Return On Assets (ROA), Non Performing Loan (NPL), Dan Inflasi Terhadap Loan To Deposit Ratio (LDR). Diponegoro Journal Of Management, 5, 1 15.

Ramzan, M., \& Zafar, M. I. (2014). Liquidity Risk Management in Islamic Banks : A Study of Islamic Banks of Pakistan. Journal Of Contemporary Research In Business, VOL 5, NO, 199-215.

Rosadaria, G. dan A. . A. R. D. (2012). Analisis Pengaruh CAR, NPL, Inflasi, Pertumbuhan DPK dan Exchange Rate Terhadap LDR (Studi Kasus Pada Bank Umum di Indonesia Periode 2004-2008). Skripsi Fakultas Ekonomika Dan Bisnis Universitas Indonesia.

Shibly, A., \& Nimsith, I. (2015). Liquidity Risk Management In Islamic And Conventional Banks In Sri Lanka : A Comparative Study. International Journal of Management, Information, Vol. 3(9 Sep 2015), 7-22.

Sinungan, M. (1993). Manajemen Dana Bank Syariah Edisi II. Jakarta: Rineka Cipta.

Sudarmadji, A. M., \& Sularto, L. (2007). Pengaruh Ukuran Perusahaan, Profitabilitas, Leverage, dan Tipe Kepemilikan Perusahaan Terhadap Luas Voluntary Disclosure. Jurnal Penelitian Fakultas Ekonomi, Universitas Gunadarma.

Sukmana, R., \& Suryaningtyas, S. (2016). Determinants Of Liquidity Risk In Indonesian Islamic And Conventional Banks. Al-Iqtishad: Jurnal Ilmu Ekonomi Syariah (Journal of Islamic Economics), 8(4), 187-200. https://doi.org/10.15408/aiq.v8i2.2871

Suryani. (2012). Analisis pengaruh Financing to Deposit Ratio (FDR) Terhadap Profitabilitas Perbankan Syariah Di Indonesia. Economica, II, 157.

Syafi'i, M. (2015). Analisis Faktor-Faktor Yang Mempengaruhi Loan To Deposit Ratio ( Studi Pada 10 Bank Terbesar Di Indonesia ). Jurnal Ilmiah.

Utari, M. P., \& Haryanto, A. M. (2011). Analisis Pengaruh CAR, NPL, ROA, Dan BOPO Terhadap LDR (Studi Kasus pada Bank Umum Swasta Nasional Devisa di Indonesia Periode 2005-2008). Skripsi Fakultas Ekonomi Dan Bisnis Universitas 


\section{Diponegoro Semarang.}

Vodova, P. (2013). Determinants Of Commercial Banks 'Liquidity In Hungary". Acta Academica Karviniensia, 13(1), 180-188. https:/ / doi.org/10.25142/aak.2013.016

Yuliani. (2007). Hubungan Efisiensi Operasional dengan Kinerja Profitabilitas Pada Sektor Perbankan Yang Go pUBLIC DI Bursa Efek Jakarta. Jurnal Manajemen Dan Bisnis Sriwijaya, 5.

Zaghdoudi, K., \& Hakimi, A. (2017). The Determinants of Liquidity Risk : Evidence from Tunisian Banks. Journal of Applied Finance E Banking, 7(2), 71-81. 